Sanel Jakupović, Ph.D.

Paneuropian University Apeiron Banja Luka, Bosnia and

Herzegovina,

sanel.e.jakupovic@apeiron-edu.eu

Vedran Šupuković

CIAK d.o.o., Zagreb, Croatia

vedran.supukovic@ciak.hr

\title{
CREDIT RISK MANAGEMENT IN THE SECONDARY MARKET FOR AUTOMOTIVE PARTS IN THE REPUBLIC OF CROATIA
}

\begin{abstract}
In recent years, there has been a dramatic decrease in the sale of new automobiles on the market of the Republic of Croatia. When considering certain periods, the sale reached its peak in 2008, with 88,265 vehicles sold. In 2013, the sale was reduced by $68.5 \%$, and 27,802 vehicles were sold. 2014 and 2015 saw a slight recovery with 35,715 vehicles sold. This increase was related to the fact that the state, through certain ministries, bought new automobiles and thus made 20\% of the above-mentioned number. Devastation in the market of new automobiles was accompanied by an increase in the sale of used vehicles, both in the country (which was caused by the fact that vehicle lease agreements of the State Administration expired, replaced by the above-mentioned share in the sales of new vehicles) and from abroad. This caused an increase in the average vehicle age in the Republic of Croatia. Consequently, the secondary market for automotive parts has been experiencing organic growth at high rates, thus determining obvious propulsiveness. The five largest companies in the secondary market for automotive parts in the Republic of Croatia generate annual revenue of HRK 1,253,655,892 (EUR 166423) through wholesale and retail. As the result of these sales methods, we have a very diverse client base in all the major companies on the market with the fundamental problem of credit risk, mainly due to the fact that the highest percentage of revenue is generated through operations with automobile repair workshops, whose balance sheet indicators are extremely poor. In such circumstances, it is essential to use a more serious approach to the problem of determining clients' creditworthiness, as the basis for better liquidity. This paper presents a
\end{abstract}


model for the assessment of clients' creditworthiness, as a possible solution to the problem of illiquidity in the Croatian secondary market for automotive parts. The model provides for the establishment of the client base, with a combination of elements of qualitative analysis and financial and quantitative analysis to assess credit risk, as well as continuous monitoring of the base. By applying this model, the credit risk of every client, as the fundamental cause of illiquidity in this sector, would be noticed on time and measures for its reduction would be taken.

Keywords: secondary market, automotive parts, credit risk, creditworthiness.

JEL: G32

\section{INTRODUCTION}

Liquidity of the Croatian economy is experiencing a constant downfall, especially liquidity of the companies dealing with products with an elastic demand. A typical example of elastic demand can be found in the automotive industry, i.e. the secondary market (aftermarket) for automotive parts. Dispersion of small clients in this market is highly expressed. Their creditworthiness affects the liquidity of individual creditors and, therefore, the liquidity of the entire secondary market for automotive parts. This is why there is a need to assess credit risks before establishing a business cooperation. The need for the client's credit risk assessment is increased by the fact that companies, in their aim to increase profit, increase their number of clients, whose economic performances vary and are often of questionable quality. In such conditions, both the conservative and liberal approach to volume of money have serious disadvantages that can result in questionable liquidity and questionable sales volume. Therefore, the formation of a client base and monitoring of the said base, both of which are presented in this paper, offers improvements related to organic growth of a company and its liquidity.

This paper analyses the creditworthiness of the five largest companies in the secondary market for automotive parts in the Republic of Croatia, which distribute their products through the following channels: 
- General wholesale directed towards companies that fulfil the narrow requirements of local markets;

- Wholesale directed towards automobile repair workshops, which, at the same time, take up the largest part of the total structure of revenues generated in the market of the Republic of Croatia;

- Wholesale through a network of franchise partners;

- General retail.

\section{SECONDARY MARKET FOR AUTOMOTIVE PARTS IN THE REPUBLIC OF CROATIA}

For better part of 2014, Croatian economy continued with a downward spiral that started in 2009, without any success in stopping the negative growth rate until the last quarter of 2014. The rising trend continued in 2015, during which Croatian economy rose by $1.6 \%$ on an annual basis. In addition, domestic demand recovered, investments into fixed capital were made and the state was spending, while the impact of export on the total GDP was negative. Such trends are a sort of inertia, partially supported in the segment of domestic demand by changes in income tax calculation. In such conditions, the aforementioned growth did in no way affect the Croatian citizens' life standard, which is reflected in the unemployment rates and value of GDP per capita. ${ }^{1}$ In 2014 , the unemployment rate was $17.30 \%$, and in 2015, it was $17.6 \%$. During the aforementioned years, the GDP per capita was EUR 12,839.37 and EUR 13,093.65, respectively.

Low standard and unemployment of citizens resulted in strengthening of the secondary market for automotive parts in the Republic of Croatia, due to constant increase in average age of vehicles. In race for profits, small locally and regionally oriented companies were gradually disappearing, either through liquidation or by being sold to larger companies, resulting in high organic growth of the largest companies in the secondary market. Basic characteristics of such secondary market for automotive parts are as follows:

\footnotetext{
${ }^{1}$ http://www.dzs.hr/Hrv_Eng/CroInFig/croinfig 2015.pdf, http://www.tradingeconomics.com/croatia/gdp-per-capita
} 
- Good quality of products in product range,

- Variety of products,

- Exceptionally large client base,

- Necessity of continuous control of the client base and liquidity management;

- High quality logistics implying fast delivery,

- Fast servicing,

- Fast delivery from the central automotive parts warehouse, etc.

\subsection{Top five companies in the secondary market for automotive parts in the Republic of Croatia}

Analysis of the largest companies in the secondary market for automotive parts in the Republic of Croatia places the company Tokić d.o.o. (Ltd) on the leading position with revenues of over 53.1 million Euros. The company started working at the beginning of the 1990s, as a family company with an initial objective to cover the market of the City of Zagreb through a retail network. Joining the ATR - the largest European trade cluster in the secondary market for automotive parts, resulted in an instant expansion of the company's business within the country through a franchise network, while operating on their own behalf and for their own account, under the Tokić d.o.o. brand. The main reason for taking that next step of expanding throughout the whole country was the fact that the contractual relationship with the ATR was based on a bonus-malus model. Therefore, it was necessary to ensure a distribution and sales capacities capable of fulfilling the obligation of purchasing goods within the ATR, functioning as a cluster with a centralized supplying function, in a short period. When it comes to profits, such a model has proven productive, but with one deficiency, which is a lack of central control of the relationships between franchise partners and their end-clients. The consequence of that was a rather liberal approach to the sale of goods by the franchise network. This, in turn, resulted in generating high liabilities, both by the end-clients towards the franchise network and from the franchise network towards the company Tokic d.o.o. (Ltd). In terms of total revenue, the second largest company is Intercars d.o.o. (Ltd). It emerged in the Croatian market in 2004, as a representative of its parent company from Poland, which had well known international 
reputation and consolidated revenue on the European market exceeding 1 billion Euros. Due to the good capitalization of the parent company, Intercars d.o.o. was provided with an opportunity for exceptional organic growth in the Croatian market through a combination of commercial policy measures and the fact that the company did all of its procurement through the parent company. This was the reason why the company did not have a liquidity gap and why it could take over the market without any setbacks. Auto Krešo d.o.o. (Ltd) occupies the third place. During the early days of development of the secondary market for automotive parts, it was the largest company with the highest growth potential. However, at the time when the company peaked, it experienced a stagnation, which came as a consequence of business egoism and resting on laurels of the past, instead of concentrating on projections for the future. On multiple occasions, this company had offers to be bought by foreign and domestic investors, but in the meantime, it was divided into three companies through which it continued with the development of its activities. The three companies were Auto Krešo store, Auto Krešo retail and Auto Krešo wholesale. The fourth place is occupied by companies CIAK Auto and CIAK Truck of the C.I.A.K. group, which were the last companies to enter the market, almost three years ago. They did this by purchasing the company Autoset, which was a legal predecessor of the company CIAK Auto, as well as by buying the companies Galanthus and Dilabor, which were legal predecessors of the company CIAK Truck, and merging them to found CIAK Truck d.o.o.

The aforementioned companies recorded the largest organic growth in the last two years by using complementary advantages stemming from the commercial capacity of the group, which deals in a much broader scope of activities.

This type of horizontal merger is subjected to criticism, because of its tendency for market monopolization. However, it is also justified economically and socially, as long as the advantages resulting from a decrease in risk outweigh the damage resulting from limitations imposed on the market (Baumol, J., W., 2002, p. 104-105). The company MB Auto, which was founded in 1994, is the largest company in the field pertaining to automotive parts for commercial 
and freight vehicles. Unlike the aforementioned companies, whose sales program includes automotive parts only for personal vehicles, with the exception of CIAK Truck, the company MB Auto is specialized in sales programs for light commercial and freight vehicles.

Table 1: Total revenues of the five largest companies in the Republic of Croatia

\begin{tabular}{|c|c|c|c|c|}
\hline \multirow[t]{2}{*}{ Company } & \multicolumn{2}{|c|}{ Business revenue in EUR } & \multirow[t]{2}{*}{ Change in \% } & \multirow{2}{*}{$\begin{array}{l}\text { Share in \% } \\
\text { in } 2015\end{array}$} \\
\hline & 2015 & 2014 & & \\
\hline Tokić d.o.o. (Ltd) & 54009521 & 41571672 & 129.92 & 32.4 \\
\hline MB Auto d.o.o. (Ltd) & 16813389 & 13706326 & 122.67 & 10.1 \\
\hline Auto Krešo & 31614236 & 23617306 & 133.86 & 19.0 \\
\hline Inter Cars d.o.o. (Ltd) & 40878619 & 28569175 & 143.09 & 24.5 \\
\hline C.I.A.K. Auto d.o.o. (Ltd) & 23274148 & 10220279 & 227.73 & 14.0 \\
\hline & 166589912 & 117684759 & 141.56 & 100.0 \\
\hline
\end{tabular}

Source: Financial Agency (FINA)

Market for automotive parts is exceptionally propulsive, with a significant organic growth recorded from year to year and a total percentage change of $41.56 \%$ in 2015 , in relation to the previous fiscal year. The highest percentage growth was realised by companies of the C.I.A.K. group, followed by Inter Cars and Auto Krešo. In terms of market share, Tokić d.o.o. held the leading position, despite the fact that even with its absolute growth of 12.4 million Euros its share decreased due to percentage growth, which was lower in comparison to market growth.

In terms of expenditures, the analysis indicates that they increase in an equivalent or even in a higher percentage than revenues do. This way, they significantly affect the same percentage level of profit in relation to total revenue, thus brining into question the usefulness of the operating leverage, as well as the matter of necessary levels of revenue required for the realisation of a profitable business. Considering the high initial expenditure structure, it is necessary to achieve exceptionally high levels of revenue that allow profitable business operations, thus limiting potential investors for that particular branch only to those with exceptional levels of capitalization. 


\section{BUSINESS ANALYSIS OF THE TOP FIVE COMPANIES}

\subsection{Basic balance sheet items of the top five companies in 2014}

Company Tokić d.o.o. has at its disposal the highest value, both regarding fixed and current assets, while the other companies have a significantly higher share of current assets. Relation between capital and liabilities is most favourable at Tokić d.o.o., where the value of liabilities is lower than capital value. Regarding the aforementioned relation, the other four companies recorded a disproportion in favour of incurring debts, which says a lot about how much they are in debt. All five companies realised a profit for the period, as well as a profit on regular business operations in the observed year.

Table 1: Basic balance sheet items of the top five automotive parts companies in 2014 (in millions EUR)

\begin{tabular}{|l|r|r|r|r|r|}
\hline Indicators & $\begin{array}{c}\text { Tokić } \\
\text { d.o.o. }\end{array}$ & $\begin{array}{c}\text { Inter } \\
\text { Cars }\end{array}$ & $\begin{array}{c}\text { Auto } \\
\text { Krešo }\end{array}$ & $\begin{array}{c}\text { C.I.A.K. } \\
\text { Auto }\end{array}$ & $\begin{array}{c}\text { MB } \\
\text { auto }\end{array}$ \\
\hline Fixed assets & 21.59 & 3.41 & 0.64 & 2.06 & 1.28 \\
\hline Current assets & 29.95 & 17.77 & 16.86 & 15.31 & 7.23 \\
\hline Capital and reserves & 26.59 & 1.71 & 7.37 & 3.20 & 1.60 \\
\hline Liabilities & 24.95 & 19.47 & 10.13 & 14.17 & 6.91 \\
\hline Profit/loss for the period & 4.45 & 0.57 & 0.39 & 0.26 & 0.75 \\
\hline $\begin{array}{l}\text { Profit/loss of regular business } \\
\text { operations }\end{array}$ & 5.01 & 0.75 & 0.52 & 0.46 & 0.29 \\
\hline
\end{tabular}

Source: http://www.fina.hr/Default.aspx

\subsection{Analysis of financial indicators of the top five companies in 2014}

Through analysis of key financial indicators of the top five companies, it is possible to determine their creditworthiness, as well as their reliability as business partners. For this purpose, the following elements were analysed: liquidity, share of profit in the capital, in the operating revenue and in the assets, level of self-financing, asset duration, asset turnover ratio, operating revenue dynamics, revenue per employee, and cash flow from the result. 
Table 2: Analysis of financial indicators of the top five automotive parts companies in Croatia in 2014

\begin{tabular}{|l|r|r|r|r|r|}
\hline Indicators & Tokić d.o.o. & Inter Cars & Auto Krešo & C.I.A.K. Auto & MB Auto \\
\hline Liquidity ratio & 1.90 & 0.89 & 1.26 & 1.05 & 1.20 \\
\hline $\begin{array}{l}\text { Quick liquidity ratio } \\
\text { Share of profit in the } \\
\text { capital, in \% }\end{array}$ & 16.89 & 0.41 & 0.63 & 0.43 & 0.77 \\
\hline $\begin{array}{l}\text { Share of profit in } \\
\text { operating revenue, in } \\
\%\end{array}$ & 8.24 & 1.39 & -2.00 & 0.20 & 4.81 \\
\hline $\begin{array}{l}\text { Share of profit in } \\
\text { assets, in \% }\end{array}$ & 8.64 & 2.69 & -25.39 & 0.30 & 8.77 \\
\hline $\begin{array}{l}\text { Level of self- } \\
\text { financing, in \% }\end{array}$ & 51.59 & 8.09 & -25.15 & 4.58 & 18.70 \\
\hline $\begin{array}{l}\text { Collection period of } \\
\text { hort-term receivables, } \\
\text { in days }\end{array}$ & 75.42 & 55.47 & 2.32 & 80.20 & 98.54 \\
\hline $\begin{array}{l}\text { Total asset turnover } \\
\text { ratio }\end{array}$ & 1.05 & 1.93 & 12.67 & 1.50 & 1.82 \\
\hline $\begin{array}{l}\text { Increase/decrease of } \\
\text { operating revenues, in } \\
\%\end{array}$ & 29.92 & 43.03 & -39.02 & 124.55 & 4.37 \\
\hline $\begin{array}{l}\text { Revenue per } \\
\text { employee, in (000) } \\
\text { HRK }\end{array}$ & $1,421.13$ & $1,404.12$ & $36,123.89$ & 771.58 & $1,175.43$ \\
\hline $\begin{array}{l}\text { Cash flow from the } \\
\text { result, u (000) HRK }\end{array}$ & $33,506.36$ & $4,286.50$ & $-2,171.94$ & 267.45 & $5,655.18$ \\
\hline
\end{tabular}

Source: http://www.fina.hr/Default.aspx

Liquidity ratio, as a relation between current assets and current liabilities, does not meet the requirements in any of the observed companies. Company Tokić d.o.o. has the most favourable liquidity, with a liquidity ratio of 1.9 , in comparison to the minimally required 2 . The quick liquidity ratio indicates a similar situation (current assetsinventories/current liabilities). At the company Tokić d.o.o., its value is 0.89 and it is close to the minimum value of 1 . The least favourable liquidity was realised at the company Inter Cars, in whose case the value of both liquidity indicators was lower by more than half of the required value.

Share of profit in the capital, measured through the profit ratio realised after taxation and the sum of the capital and reserves, is high in all 
companies, with the exception of C.I.A.K. Satisfactory share of profit in the operating revenue was realised in the company Tokić d.o.o., while the share was not realised in the company Auto Krešo (-2\%). The company Auto Krešo realised a negative share of profit in the assets $(-25.39 \%)$ and a negative level of self-financing $(-25.15 \%)$. The highest level of self-financing was realised at Tokić d.o.o. (51.59\%) and $\mathrm{MB}$ auto (18.70\%).

The company MB Auto has the longest collection period of short-term receivables (98.54 days), and Auto Krešo the shortest (2.32 days).

Auto Krešo has the only satisfactory total asset turnover ratio (12.67), while in the other companies the aforementioned ratio is lower than 2. Operating revenue growth was highest in C.I.A.K. Auto (124.55\%), while the company Auto Krešo recorded a fall of $39.02 \%$

The highest revenue per employee was realised in the company Auto Krešo (EUR 36,123.89), and the lowest in C.I.A.K. Auto (EUR 771.58).

Finally, in terms of cash flow from the result, it is noticeable that the company Tokić d.o.o. generates the largest amount of sound money from its business operations. A negative cash flow is recorded in the company Auto Krešo (EUR -2171.94).

\subsection{Duration of the cycle from procurement to sale in the top five companies in 2014}

An important indicator for evaluating creditworthiness is the duration of the cycle from procurement to sale. A shorter cycle indicates that cash turnover is carried out more quickly and that inventories are held in the warehouse for a shorter period. Average cycle duration (from charging to payment) was longest in the company Auto Krešo - 85 days, and it was 49 days shorter in comparison with the previous year. Average cycle duration in the sector was decreased by $62 \%$, and lasted 32 days.

Average duration of retention of inventories was longest in the company MB auto (141 days), and it was 43 days longer than the average value in the sector. Average collection period of short-term 
receivables is shorter in comparison to the average period for payment of liabilities, and this relates to all the companies. Longer average collection period (75 days) and payment period (140 days) are characteristic for the automotive parts sector.

The aforementioned data points to a large standstill regarding cash, both in inventories and in collection of receivables. At the same time, overcoming of illiquidity in this sector can be executed by stalling when paying liabilities, as a form of covert financing.

Table 3: Duration of the cycle from procurement to sale in the top five companies in 2014

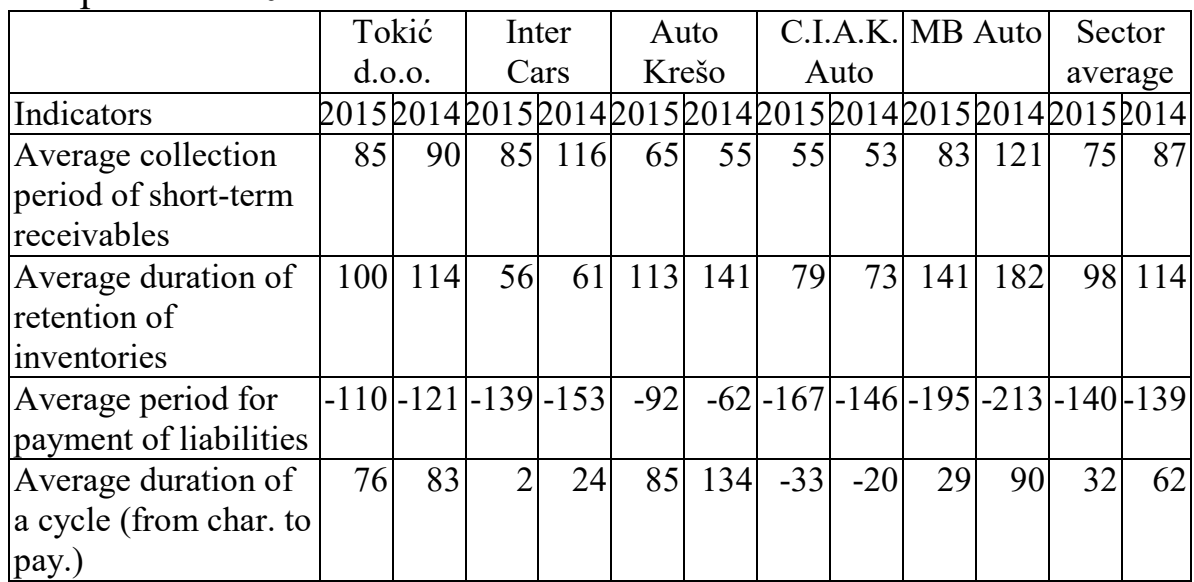

Source: $\underline{\text { http://www.fina.hr/Default.aspx }}$

\subsection{Altman financial distress ratio (Z-score) of the observed companies}

Altman financial distress ratio (Zeta score) unites the key financial indicators: liquidity indicator (X1), retained profit/total assets ratio (X2), profitability indicator (X3), ratio between capital and total liabilities (X4) and the ability of the management to generate revenue by using company assets (X5). Listed indicators are multiplied with specified weightings, and their sum represents the financial distress ratio. Financial distress ratio is expressed through the following equation (James, C.V., 1997, 782-783) 


\section{$\mathrm{Z}=1.2 \mathrm{X} 1+1.4 \mathrm{X} 2+3.3 \mathrm{X} 3+0.6 \mathrm{X} 4+1.0 \times 5$}

If the Z-score is lower than 1, the company has financial difficulties. The "grey area" of business operations of a company is measured by values between 1 and 3, while a score higher than 3 points to stable business operations.

Table 4: Altman financial distress ratio of the top five automotive parts companies in Croatia in 2014

\begin{tabular}{|l|l|l|l|l|l|l|l|l|l|l|}
\hline & \multicolumn{2}{|c|}{ Tokić d.o.o. } & Inter Cars & \multicolumn{2}{|c|}{ Auto Krešo } & \multicolumn{3}{|c|}{ C.I.A.K. Aut } & \multicolumn{2}{|c|}{ MB Auto } \\
\hline Indicators & 2015 & 2014 & 2015 & 2014 & 2015 & 2014 & 2015 & 2014 & 2015 & 2014 \\
\hline Zeta score indicator & 2.39 & 2.47 & 1.80 & 1.91 & 2.92 & 3.09 & 1.86 & 1.56 & 2.72 & 1.72 \\
\hline
\end{tabular}

Source: http://www.fina.hr/Default.aspx

From the analysis of the Altman financial distress ratio, one can clearly see that the Zeta score for most of the competitors is in the range between 1 and 3, which classifies them as "grey area" companies (Alihodžić, 2012, 58-64). The lowest Zeta score was recorded by Inter Cars (1.80). In comparison to 2014, MB Auto and C.I.A.K. Auto recorded an increase in the Zeta score, while other companies recorded a decrease, and Auto Krešo recorded the best Zeta score.

\section{CREDIT RISK MANAGEMENT BY USING CLIENT BASE MONITORING}

By using available resources of all existing clients, whether they are local wholesale or retail clients, a potential franchise network or an automobile repair workshop, strict control of every business operation segment is imposed as an imperative. This case is especially emphasized as this is the time of relatively high rates of organic growth of certain companies and the time in which smaller wholesale clients working in the small local market cease their business operations. The fundamental management problem deals with credit risk management when the client base is dispersed. For this purpose, it is necessary to build the client base, and to start with its monitoring. In this case, every active client becomes the subject of continuous 
monitoring on a daily or periodical basis, in accordance with the following parameters:

It is necessary to enter the following data in the database of every buyer:

- Year (date) of establishment,

- Registration,

- Legal form,

- Capital,

- Shareholders (owners of business shares),

- Management Board,

- Functions of persons in other companies,

- Associated companies,

- Bankruptcy proceedings/legal proceedings,

- Maximum credit and deferral of payment,

- Credit risk assessment (expressed on a scale from 0 (bankruptcy proceedings / preliminary proceedings / proceedings related to collection of receivables) to 10 (almost no risk). The scale shows the probability of halt within the next 12 months, counting from the date when the scale was made),

- Payments,

- Additional description,

- Collection of receivables.

The database would also include the most important business performances of the client, such as:

- Illiquidity/transaction account freeze,

- Insolvency (when liabilities exceed the value of total assets),

- Rehabilitation procedure,

- Bankruptcy proceedings or liquidation,

- Changes in the result on a time scale,

- Changes in business and ownership structure of active clients,

- Forced collection/enforcement,

- Level of risk (credit, currency, interest rate, market).

- This monitored client base enables us to classify and manage the risk through a certain credit limits and high-quality projection of inflows and collection in an adequate way. 
- Significant dispersion of buyers in the secondary market for automotive parts implies the necessity for reliable assessment of their creditworthiness, as well as the necessity for the establishment of creditworthiness base.

The portfolio has to be monitored and cleaned of useless receivables items in a continuous and timely manner so that the collection of receivables would not become complicated. The sophisticated method of portfolio monitoring is established by monitoring individual clients' credit risk rate. Clients classified as high-risk clients or those whose rate is above the medium risk are put in the system of "permanent blockage of delivery of goods and services". At the same time, it is necessary to take urgent measures for collection of outstanding debts, by freezing partner status until the improvement of economic parameters in the base.

For the purpose of this research, the base of 451 clients, classified into the following risk categories, was monitored:

Table 5: Risk classification of the portfolio consisting of 451 clients from the automotive parts sector

\begin{tabular}{|l|r|r|}
\hline Risk level & $\begin{array}{l}\text { No. of } \\
\text { clients }\end{array}$ & Group share \\
\hline High risk & 51 & $11.31 \%$ \\
\hline Above medium risk & 73 & $16.19 \%$ \\
\hline Medium risk & 32 & $7.10 \%$ \\
\hline Low risk & 236 & $52.33 \%$ \\
\hline No risk & 59 & $13.08 \%$ \\
\hline TOTAL & 451 & $100.00 \%$ \\
\hline
\end{tabular}

Categorization of clients into risk groups is performed based on financial and non-financial data from the base, which are variable in character and are subject to continuous monitoring. Credit risk assessment is expressed on a scale from 0 (bankruptcy proceedings / preliminary proceedings / proceedings related to collection of receivables) to 10 (almost no risk). The scale shows the probability of halt within the next 12 months, counting from the date when the scale was made. The research shows there is significant representation of high-risk companies $(86.93 \%)$, which appear as automotive parts 
buyers, and that such tendency can threaten the liquidity position of the automotive parts sector, and thus of the other sectors connected with it directly or indirectly.

\section{CONCLUSION}

The approach to this subject was based on the risk assessment of five largest companies in the secondary market for automotive parts in the following manner:

- We combined quantitative analysis (analysis according to financial indicators) with qualitative assessment,

- We presented a model of statistical possibility of insolvency for the period of next 12 months, by giving rating score to companies in the examples described,

- We summarized every key factor for the objective assessment of credit risk and presented it on the exact scale;

In the process of base formation, we used a combination of results from the qualitative model and financial and quantitative model. Data used as qualitative indicators relate to the age of company, legal form - legislative framework and acquis, location of the company geographical position in the country, company development and activities - national classification of company size, information on shareholders, owners of business shares and Management Board and information on payment.

When it comes to financial and quantitative indicators, we used the following indicators: liquidity ratio, quick liquidity ratio, share of profit in capital, share of profit in operating revenue, share of profit in assets, level of self-financing, collection period of short-term receivables in days, total asset turnover ratio, increase/decrease in operating revenues, revenue per employee.

All this should enable the creation of conditions for decision-making with greater reliability in order to timely detect any negative deviations that may hinder the operations in the secondary market for automotive parts, especially regarding credit risks, as the main cause of illiquidity, both in this sector and in whole national economy. By 
better assessment of risk development and appropriate management, companies would be able to use their future opportunities better and thus improve the level of collectability of receivables. The explained approach to client base monitoring emphasizes the liquidity on the secondary market for automotive parts in the Republic of Croatia.

\section{LITERATURE}

1. Bomol, J.W. (2002), The Free-Market Innovation Machine analysing the growth miracle of capitalism, Princeton University Press, Princeton, USA

2. James, C.V., (1997), Financijsko upravljanje i politika, Mate, Zagreb,

3. Alihodžić, A. (2012), Modeli za predviđanje finansijskih neprilika, Časopis ZIPS, br.1248, Sarajevo,

4. FINA

5. http://www.dzs.hr/Hrv Eng/CroInFig/croinfig_2015.pdf,

6. http://www.tradingeconomics.com/croatia/gdp-per-capita 